\title{
PENGARUH KEMUDAHAN, PROMOSI, DAN KEMANFAATAN TERHADAP KEPUTUSAN PENGGUNAAN UANG DIGITAL
}

\author{
Fitriani Latief ${ }^{* 1}$, Dirwan ${ }^{2}$ \\ ${ }^{1,2}$ Jurusan Manajemen, Sekolah Tinggi Ilmu Ekonomi Nobel Makassar, \\ Sulawesi Selatan, Indonesia \\ e-mail: fitri@stienobel-indonesia.ac.id
}

\begin{abstract}
ABSTRAK
Perkembangan sistem pembayaran digital saat ini memunculkan berbagai alternatif dalam penggunaannya demikian juga promosi yang diberikan kepada setiap nasabah atau konsumen pengguna. Beberapa kelebihan yang ditawarkan oleh uang digital ialah kemudahan transaksi, efisiensi waktu dan kemudahan isi ulang. Penelitian ini bertujuan untuk mengetahui pengaruh kemudahan, promosi dan kemanfaatan terhadap keputusan penggunaan uang digital di Kota Makassar. Data yang digunakan dalam penelitian ini merupakan data primer diperoleh dengan cara menyebarkan kuesioner kepada pengguna layanan uang elektronik atau digital. Hasil penelitian menunjukkan bahwa faktor kemudahan dan kemanfaatan berpengaruh positif dan signifikan terhadap keputusan penggunaan uang digital sedangkan aktivitas promosi tidak siginifikan memengaruhi keputusan penggunaan. Secara simultan, kemudahan, promosi dan kemanfaatan berpengaruh secara bersama-sama terhadap keputusan penggunaan yang digital.
\end{abstract}

\section{Kata Kunci: Penggunaan Uang Digital, Kemudahan Akses, Promosi, Kemanfaatan}

\begin{abstract}
The development of digital payment system has led to various alternatives in its use as well as promotions given to every costumer. Some of the advantages offered by digital money are easy to use in transaction, efficiency and ease of refill. This study aims to find the effect of convenience, promotion, and usefulness on decision to use digital money in Makassar City. The data use of this study are primary data obtained by questionnaires to users of electronic or digital money service. The results showed that ease and usefulness factor had a positive and significant effect on the decision to use digital money while promotion did not significantly influence the decision to use it. Based on simultaneous effect But simultaneously, convenience, promotion, and usefulness simultaneusly jointly influence digital usage decisions.
\end{abstract}

Keywords: Digital Money Usage, Convenience, Promotion, Usefulness 


\section{PENDAHULUAN}

Uang kertas yang telah digunakan selama berabad-abad sebagai alat transaksi mengalami perubahan signifikan dengan mengusung konsep paperless. Konsep tersebut merupakan salah satu solusi untuk menyikapi isu lingkungan terkait masifnya penebangan pohon untuk memenuhi kebutuhan kertas dunia. Pada tahun 1946, telah mulai muncul alat transaksi alternatif yaitu dalam bentuk kartu. Tujuan adanya alat transaksi berupa kartu ialah agar masyarakat tidak perlu membawa uang kertas dalam jumlah banyak namun cukup dengan hanya membawa 1 kartu saja.

Kemajuan teknologi di era disrupsi membawa perubahan signifikan pada kebiasaan manusia. Hal tersebut dapat diperhatikan pada berbagai jenis aplikasi yang tersedia di mobile phone. Kemudahan tersebut menunjang aktivitas manusia termasuk dalam melakukan transaksi keuangan. Alat transaksi yang dihasilkan dari proses disrupsi terhadap alat tukar konvensional ialah hadirnya uang digital (e-money). Uang digital di Indonesia pertama kali diatur melalui Peraturan Bank Indonesia no. 11/12/PBI tahun 2009. Hadirnya regulasi terkait uang digital merupakan bentuk pengakuan terhadap keabsahan uang digital sebagai alat transaksi yang diakui oleh Negara [1].

Beberapa kelebihan yang ditawarkan oleh uang elektronik ialah kemudahan proses transaksi, efisiensi waktu transaksi, dan dapat diisi ulang melalui berbagai fasilitas yang disediakan oleh penerbit. Penyedia uang digital dapat menyediakan layanan dengan berbasis chip (kartu) maupun server. Uang elektronik berbasis chip seperti Brizzi dan Flazz sedang uang elektronik berbasis server yaitu OVO, GoPay, LinkAja, dan ShopeePay.

Berbagai kemudahan dan kelebihan yang ditawarkan oleh uang digital, secara teoritis, dapat membuat masyarakat bermigrasi dari alat transaksi konvensional (uang kertas) ke uang digital. Menurut Bank Indonesia jumlah pengguna uang digital di Indonesia pada interval tahun 2015 - 2017 menunjukkan peningkatan lebih dari dua kali lipat yaitu 34.314.795 pengguna pada tahun 2015 menjadi 90.003.848 pengguna pada tahun 2017, [2]. Peningkatan tersebut menunjukkan bahwa manfaat dan kemudahan dalam bertransaksi menggunakan uang elektronik menumbuhkan minat masyarakat menggunakan mobile payment [3], [4], [5].

Meningkatnya perdagangan di Indonesia tidak terlepas dari hadirnya uang digital yang memudahkan proses transaksi antara penjual dan pembeli [6]. Kondisi tersebut diperkuat oleh berbagai program promosi yang ditawarkan oleh penerbit uang digital. Adanya 
promosi uang digital berpengaruh positif terhadap keputusan penggunaan uang elektronik di masyarakat [7].

Uang adalah asset yang secara umum dapat diterima sebagai alat pembayaran barang dan jasa atau utang [8]. Uang memiliki fungsi dasar sebagai alat tukar dan alat penyimpan nilai sedangkan fungsi tambahannya yaitu sebagai satuan hitung dan ukuran untuk pembayaran masa depan [9].

Uang elektronik secara harfiah adalah alat pembayaran yang proses transaksinya menggunakan fasilitas elektronik berupa chip atau server. Berdasarkan regulasi Bank Indonesia maka uang elektronik harus memenuhi unsur; (1) diterbitkan atas dasar nilai uang yang disetor terlebih dahulu oleh pemegang kepada penerbit, (2) nilai uang disimpan secara elektronik dalam suatu media seperti chip atau server, (3) digunakan sebagai alat pembayaran kepada pedagang yang bukan merupakan penerbit uang elektronik tersebut, dan (4) nilai uang elektronik yang disetor oleh pemegang dan dikelola oleh penerbit bukan merupakan simpanan sebagaimana dijelaskan dalam Undang-Undang Perbankan [2].

Berdasarkan medianya maka uang elektronik dapat berbasis kartu (chip) dan jaringan (server). Berdasarkan penggunaannya maka dapat berbentuk single-purpose dan multipurpose. Uang elektronik dapat digunakan untuk beberapa keperluan transaksi seperti pembayaran, pengisian ulang, tarik tunai, dan refund.

Kemudahan penggunaan (ease of use) adalah derajat dimana seseorang meyakini bahwa melalui penerapan teknologi maka akan membebaskan orang dari beberapa usaha [10]. Semakin tinggi kemudahan seseorang untuk mengaplikasikan sistem atau teknologi maka semakin tinggi tingkat kemanfaatannya [11]. Berdasarkan Venkatesh dkk. kemudahan terbagi atas berbagai unsur. Unsur tersebut yaitu ; (1) sistem mudah dimengerti, (2) praktis, dan (3) terjangkau [12].

Selain itu, kegiatan promosi bertujuan untuk memengaruhi perilaku pembeli dengan memberitahu, membujuk, dan mengingatkan [13]. Promosi merupakan sarana komunikasi eksternal penyedia jasa/barang untuk memotivasi calon pembeli agar melakukan transaksi [14]. Aktivitas promosi uang digital dilakukan untuk memotivasi masyarakat agar berpindah dari alat tukar konvensional ke alat tukar digital. Kegiatan promosi menurut Kotler dan Keller yaitu; (1) iklan, (2) fasilitas penjualan, (3) publikasi melalui acara, dan (4) pemasaran langsung [15]. 
Manfaat dalam kaitannya dengan perkembangan teknologi yaitu pandangan subjektif pengguna atas penggunaan aplikasi untuk memudahkan pekerjaannya [16]. Kemanfaatan merupakan bangunan kepercayaan individu bahwa teknologi yang digunakan membantu meningkatkan kinerja mereka [17]. Manfaat uang digital terhadap perekonomian Indonesia yaitu meningkatkan kepuasan konsumen dan peningkatan kecepatan, transparansi, dan akuntabilitas transaksi [2]. Kemanfaatan dapat diukur berdasarkan; (1) kemampuan mempercepat proses, (2) kemampuan meningkatkan efektivitas, (3) memberi manfaat langsung bagi individu, dan (4) kemampuan meningkatkan produktivitas individu.

Keputusan konsumen untuk membeli barang/jasa merupakan proses integrasi pengetahuan untuk melakukan evaluasi terhadap dua atau lebih perilaku dan kemudian memilih salah satunya [18]. Setiap saat, secara tidak sadar, konsumen melakukan pengambilan keputusan dengan membandingkan beberapa pilihan yang relevan dengan barang/jasa yang akan dikonsumsi. Pengambilan keputusan melalui beberapa tahapan yang dilakukan secara sadar maupun tidak sadar. Tahapan dalam proses pengambilan keputusan yaitu; (1) pengenalan masalah, (2) penelusuran informasi, (3) membandingkan alternatif pilihan, (4) keputusan, dan (5) respon pasca penggunaan [15].

Hasil penelitian Indayanto dan Susilo (2015) menunjukan bahwa persepsi kemanfaatan berpengaruh signifikan terhadap minat menggunakan akun rekening secara kolektif [19]. Novianti dkk (2017) dalam penelitiannya menyimpulkan bahwa persepsi kegunaan berpengaruh positif terhadap minat pengguna instagram untuk berbelanja secara daring [20]. Hasil berbeda diperoleh Rafidah (2017) yang menyatakan bahwa kemudahan tidak berpengaruh signifikan terhadap keputusan berbelanja on-line [21].

Fontes dkk. (2017) dan Di Pietro dkk. (2015) pada penelitiannya menemukan bahwa dimensi kemanfaatan dan kemudahan berpengaruh positif terhadap minat menggunakan sistem pembayaran elektronik [3], [4]. Selain itu, kegiatan promosi berpengaruh positif terhadap minat menggunakan uang digital [7].

Berdasarkan teori dan beberapa penelitian terdahulu maka tujuan penelitian ini adalah untuk mengetahui; (1) pengaruh kemudahan terhadap keputusan penggunaan uang digital, (2) pengaruh promosi terhadap keputusan penggunaan uang digital, (3) pengaruh kemanfaatan terhadap keputusan penggunaan uang digital, dan (4) pengaruh kegunaan, promosi, dan kemanfaatan terhadap keputusan penggunaan uang digital. 


\section{METODE PENELITIAN}

\subsection{Desain Penelitian}

Penelitian menggunakan metode kuantitatif yaitu menggunakan data berupa angka untuk melakukan analisis statistik dan uji efek [22]. Hipotesis yang dibangun merupakan bentuk hubungan kausal antara variabel independen (kemudahan, promosi, kemanfaatan) dan variabel dependen (keputusan penggunaan). Uji efek menggunakan metode regresi linear berganda (uji parsial dan simultan) dengan terlebih dahulu melakukan uji kualitas data (validitas dan reliabiliitas) dan asumsi klasik (normalitas, multikolinearitas, dan heteroskedastisitas) [22].

\subsection{Populasi dan Sampel}

Populasi pada penelitian ini adalah pengguna uang digital di Kota Makassar. Penentuan sampel menggunakan simple random sampling. Berhubung populasi pengguna uang digital tidak diketahui secara pasti maka jumlah sampel dihitung menggunakan rumus sebagai berikut [23].

$$
\begin{aligned}
n= & \left(\frac{Z \alpha / 2 \sigma}{e}\right)^{2}=\left(\frac{1,96 \times 0,25}{0,05}\right)^{2} \\
& =96,04 \approx 97
\end{aligned}
$$

Berdasarkan hasil perhitungan tersebut maka jumlah sampel dalam penelitian ini sebanyak 97 responden.

\subsection{Teknik Pengumpulan Data}

Pengumpulan data primer dari responden menggunakan instrumen kuesioner. Tanggapan responden diukur menggunakan skala likert $1-5$. Untuk menunjang pembahasan penelitian maka diperlukan data sekunder. Data sekunder pada penelitian ini berasal dari studi pustaka maupun sumber lain yang relevan dengan topik penelitian.

\subsection{Metode Analisis}

Analisis data yang digunakan ialah statistik inferensial dengan model regresi linear berganda. Persamaan model regresi linear berganda yang digunakan ialah sebagai berikut:

$$
Y=\alpha+\beta_{1} X 1+\beta_{2} X 2+\beta_{3} X 3+e
$$




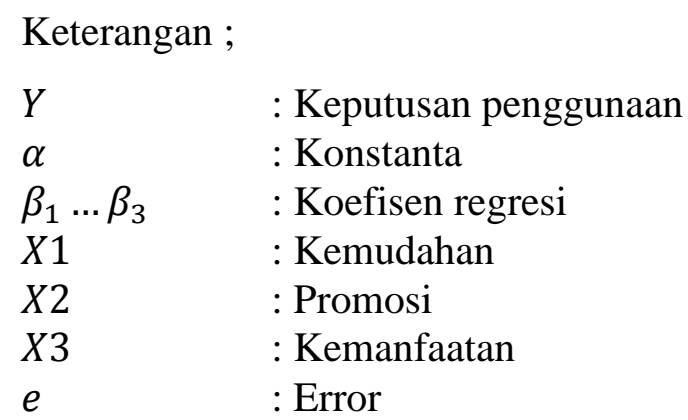

Untuk mengaplikasikan model regresi linear berganda maka terlebih dahulu dilakukan uji validitas dan reliabilitas data. Agar terhindar dari bias maka model regresi yang dibuat harus memenuhi asumsi klasik yaitu normalitas, multikolinearitas, dan heteroskedastisitas.

Penarikan kesimpulan uji efek terkait hubungan variabel independen dan dependen berdasarkan nilai signifikan yang dihasilkan. Tingkat kesalahan yang dapat diterima ialah 5\% sehingga variabel independen dinyatakan berpengaruh terhadap variabel dependen apabila memiliki nilai signifikansi lebih kecil dari 5\% $(\alpha=0,05)$.

\section{HASIL DAN PEMBAHASAN}

\subsection{Karakteristik Responden}

Responden pada penelitian ini adalah para pengguna uang digital yang tinggal di Kota Makassar. Jumlah responden sebanyak 97 responden. Karaktersitik responden mencakup umur, jenis uang digital, dan intensitas pemakaiannya.

\section{Tabel 1. Jumlah Responden Berdasarkan Umur}

\begin{tabular}{ccc}
\hline Umur & Frekuensi & Persentase \\
\hline $15-25$ & 37 & 38,14 \\
$26-35$ & 22 & 22,68 \\
$36-45$ & 28 & 28,87 \\
$>45$ & 10 & 10,31 \\
Total & $\mathbf{9 7}$ & $\mathbf{1 0 0 , 0 0}$ \\
\hline \multicolumn{2}{l}{ Sumber : Olah data, 2019 }
\end{tabular}

Umur responden dominan yaitu pada kelompok umur 15 - 25 tahun $(38,14 \%)$. Kelompok umur tersebut merupakan generasi millenial yang tumbuh dewasa bersama perkembangan teknologi sehingga individu pada kelompok umur tersebut telah akrab dengan konsep digital. 
Tabel 2. Jenis Uang Digital yang Sering Digunakan

\begin{tabular}{lcc}
\hline Jenis & Frekuensi & Persentase \\
\hline OVO & 46 & 47,42 \\
GoPay & 24 & 24,74 \\
LinkAja & 6 & 6,19 \\
T-Cash & 8 & 8,25 \\
Dana & 3 & 3,09 \\
M-banking & 10 & 10,31 \\
Total & $\mathbf{9 7}$ & $\mathbf{1 0 0 , 0 0}$ \\
\hline Sumber : Olah data, 2019 &
\end{tabular}

Uang digital OVO dominan digunakan oleh masyarakat (47,42\%). Selain OVO, terdapat pula GoPay $(24,74 \%)$ dan M-banking $(10,31 \%)$ yang persentasenya di atas $10 \%$.

Tabel 3. Intensitas Pemakaian Uang Digital Responden (Transaksi/Pekan)

\begin{tabular}{lcc}
\hline \multicolumn{1}{c}{ Intensitas pemakaian } & Frekuensi & Persentase \\
\hline $1-5$ & 6 & 6,19 \\
$6-10$ & 25 & 25,77 \\
$11-15$ & 40 & 41,24 \\
$16-20$ & 16 & 16,49 \\
$>20$ & 10 & 10,31 \\
Total & $\mathbf{9 7}$ & $\mathbf{1 0 0 , 0 0}$ \\
\hline
\end{tabular}

Sumber : Olah data, 2019

Mayoritas responden menunjukkan intensitas pemakaian uang digital $11-15$ transaksi setiap pekan $(41,24 \%)$. Intensitas tersebut menunjukkan bahwa mayoritas responden menggunakan uang digital secara intensif $2-3$ kali per hari.

\subsection{Kualitas Data}

\section{Uji Validitas}

Pengujian validitas dilakukan untuk mengetahui valid/tidak validnya item pertanyaan pada kuesioner yang digunakan untuk mengukur variabel. Berikut ini hasil uji validitas berdasarkan nilai korelasi antara indikator dan nilai total setiap variabel. 
Tabel 4. Hasil Uji Validitas

\begin{tabular}{llrl}
\hline \multicolumn{1}{c}{ Variabel } & Indikator & Korelasi & Ket. \\
\hline Kemudahan & X1_1 & 0,768 & Valid \\
(X1) & X1_2 & 0,827 & Valid \\
& X1_3 & 0,769 & Valid \\
& X1_4 & 0,808 & Valid \\
Promosi & X1_5 & 0,732 & Valid \\
(X2) & X2_1 & 0,738 & Valid \\
& X2_2 & 0,847 & Valid \\
& X2_3 & 0,909 & Valid \\
Kemanfaatan & X2_4 & 0,866 & Valid \\
(X3) & X3_5 & 0,656 & Valid \\
& X3_2 & 0,651 & Valid \\
& X3_3 & 0,884 & Valid \\
& X3_4 & 0,902 & Valid \\
Keputusan & X3_5 & 0,908 & Valid \\
penggunaan & Y_1 & 0,715 & Valid \\
(Y) & Y_2 & 0,743 & Valid \\
& Y_3 & 0,794 & Valid \\
& Y_4 & 0,755 & Valid \\
& Y_5 & 0,738 & Valid \\
& Y_6 & 0,832 & Valid \\
Sumber : Olah data, 2019 & 0,839 & Valid \\
\hline & & &
\end{tabular}

Merujuk pada nilai korelasi antara tiap indikator dan skor total setiap variabel diketahui setiap indikator memiliki nilai korelasi lebih besar dari 0,300. Nilai tersebut menunjukkan bahwa setiap pernyataan yang digunakan untuk mengukur indikator dan variabel dapat dinyatakan valid.

\section{Uji Reliabilitas}

Pengukuran reliabilitas dilakukan untuk mengetahui kehandalan instrumen kuesioner yang digunakan untuk mengukur terkait konsistensi responden untuk menjawab pertanyaan pada kuesioner.

Tabel 5. Hasil Uji Reliabilitas

\begin{tabular}{lcc}
\hline \multicolumn{1}{c}{ Variabel } & Cronbach Alpha & Ket. \\
\hline Kemudahan (X1) & 0,831 & Reliabel \\
Promosi (X2) & 0,866 & Reliabel \\
Kemanfaatan (X3) & 0,870 & Reliabel \\
Keputusan & 0,872 & Reliabel \\
penggunaan (Y) & & \\
\hline Sumber : Olah data, 2019 & &
\end{tabular}


Nilai reliabilitas ditunjukkan pada kolom Cronbach Alpha dengan kriteria 0,600 sebagai nilai minimum variabel dapat dinyatakan reliabel (handal). Mengacu pada Tabel maka diketahui setiap variabel memiliki nilai Cronbach Alpha antara 0,800 - 0,900 sehingga dapat disimpulkan bahwa variabel yang digunakan pada penelitian telah memenuhi kriteria reliabilitas.

\subsection{Asumsi Klasik}

\section{Uji Normalitas}

Asumsi normalitas digunakan untuk memastikan sebaran data residual mengikuti pola distribusi normal. Asumsi normalitas penting untuk menentukan teknik pengujian data yang akan diimplementasikan (parametrik atau nonparametrik). Berikut ini grafik normal plot yang menunjukkan sebaran residu data.

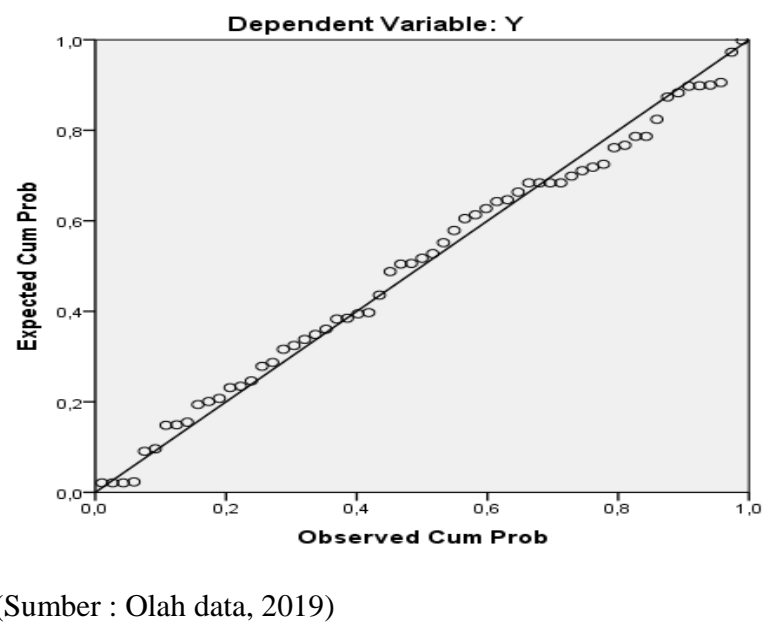

Gambar 1. Grafik Normal Plot

Berdasarkan sebaran residu data pada grafik normal plot diketahui bahwa sebaran data berada di sekitar garis diagonal rata-rata. Oleh karena itu dapat disimpulkan bahwa data telah memenuhi asumsi normalitas.

\section{Uji Multikolinearitas}

Uji multikolinearitas digunakan untuk memastikan bahwa antar variabel independen tidak terjadi korelasi kuat. Apabila terjadi multikolinearitas maka uji efek antara variabel independen dan dependen berpotensi bias. Pengujian multikolinearitas berdasarkan nilai Tolerance $(\geq 0,10)$ dan VIF $(<10)$. Hasil pengujian dapat diperhatikan pada tabel berikut. 


\section{Tabel 6. Hasil Uji Multikolinearitas}

\begin{tabular}{lcrl}
\hline Variabel & Tolerance & VIF & Ket. \\
\hline X1 & 0,485 & 2,062 & Bebas multikolinearitas \\
X2 & 0,291 & 3,431 & Bebas multikolinearitas \\
X3 & 0,249 & 4,015 & Bebas multikolinearitas \\
\hline Sumber : Olah data 2019 & &
\end{tabular}

Sumber : Olah data, 2019

Berdasarkan pada Tabel 6 maka dapat disimpulkan bahwa setiap variabel independen bebas dari multikolinearitas. Oleh karena itu dapat disimpulkan bahwa variabel independen yang digunakan dapat diimplementasikan untuk diuji kaitannya dengan variabel dependen.

\section{Uji Heterokedastisitas}

Heterokedastisitas dilakukan untuk mengetahui ada/tiadanya kesamaan varian residual antar pengamatan. Pengujian asumsi heterokedastisitas menggunakan sebaran data residu pada grafik scatter plot dengan kriteria bahwa sebaran data tidak membentuk pola tertentu.

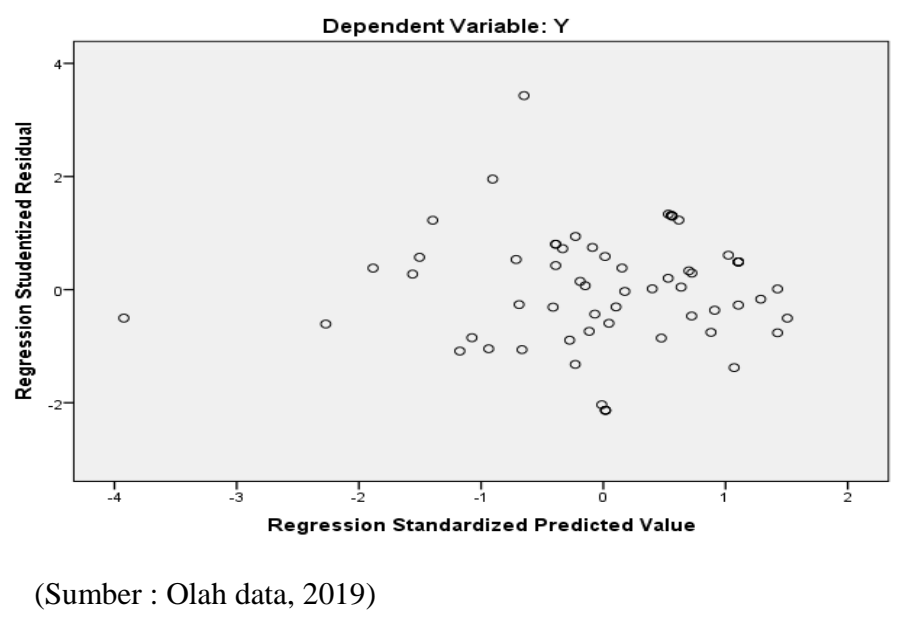

Gambar 2. Grafik Scatterplot

Pada Gambar 2 dapat diperhatikan bahwa data tersebar tidak membentuk pola tertentu. Oleh karena itu dapat disimpulkan bahwa data tidak mengandung heterokedastisitas.

\subsection{Hasil Analisis Regresi}

Data yang telah dikumpulkan telah diuji dan dinyatakan memenuhi asumsi klasik sehingga dapat digunakan untuk menguji hubungan antar variabel. Pengujian tersebut menggunakan model regresi linear berganda. Berdasarkan hasil pengolahan data maka diperoleh persamaan regresi berganda sebagai berikut: 


$$
Y=-0,525+0,633 X 1+0,313 X 2+0,850 X 3
$$

Tabel berikut merupakan rangkuman dari hasil pengolahan data dengan model regresi berganda $(\alpha=5 \% ; 0,05)$.

Tabel 7. Hasil Perhitungan Model Regresi Berganda

\begin{tabular}{rlccc}
\hline & Model & Koef. & Sig. & Ket. \\
\hline 1 & X1 -> Y & 0,633 & 0,000 & Diterima \\
2 & X2 -> Y & 0,313 & 0,069 & Ditolak \\
3 & X3 -> Y & 0,850 & 0,000 & Diterima \\
4 & X1, X2, & - & 0,000 & Diterima \\
& X3 -> Y & & \\
Koef. R : 0,832 \\
\multicolumn{4}{l}{ Koef. R ${ }^{2}: 0,691$} \\
\multicolumn{5}{l}{ Sumber : Olah data, 2019}
\end{tabular}

1. Koefisien variabel Kemudahan (X1) menunjukkan nilai +0,633 dan nilai sig. 0,000. Hasil tersebut menunjukkan level signifikansi diterima (sig. $0,000<\alpha=0,05$ ) bahwa kemudahan berpengaruh positif terhadap keputusan penggunaan uang digital. Setiap peningkatan kemudahan layanan mampu meningkatkan atau meyakinkan pengguna uang digital sebesar 0,633 .

2. Koefisien variabel Promosi (X2) sebesar $+0,313$ dengan nilai signifikan $+0,069$. Interpretasi dari hasil tersebut ialah variabel promosi berkontribusi positif terhadap keputusan penggunaan uang digital sebesar 0,069 namun tidak berpengaruh secara signifikan (sig. 0,069> $\alpha=0,05$ ) sehingga hipotesis ditolak.

3. Koefisien variabel Kemanfaatan (X3) sebesar $+0,850$ dan nilai signifikan 0,000. Hasil tersebut menunjukkan level signifikansi diterima (sig. $0,000<\alpha=0,05$ ) bahwa kemanfaatan berpengaruh positif terhadap keputusan penggunaan uang digital. Setiap peningkatan manfaat dari uang digital dapat meningkatkan atau menguatkan keputusan masyarakat untuk menggunakan uang digital sebesar 0,850.

4. Kemudahan (X1), Promosi (X2), dan Kemanfaatan (X3) berpengaruh positif secara simultan terhadap Keputusan Penggunaan uang digital

5. Berdasarkan nilai koefisien determinan $\left(\mathrm{R}^{2}\right)$ maka diketahui bahwa variabel kemudahan, promosi, dan kemanfaatan mampu menjelaskan 69,10\% bagian dari keputusan penggunaan uang digital sedangkan sisanya 30,90\% dipengaruhi oleh faktor lain di luar model penelitian. 


\subsection{Pembahasan}

\section{Pengaruh Kemudahan Terhadap Keputusan Penggunaan Uang Digital}

Hasil analisis menyimpulkan bahwa kemudahan (easy to use) sistem transaksi uang digital berpengaruh positif terhadap keputusan masyarakat untuk menggunakan uang digital. Kesimpulan tersebut menguatkan hasil penelitian sebelumnya yang menyimpulkan bahwa persepsi kemudahan berpengaruh terhadap minta masyarakat untuk bertransaksi online [3], [5].

Sistem uang digital menawarkan konsep transaksi yang mudah untuk dijangkau. Integrasi uang digital ke mobile phone melalui aplikasi semakin memudahkan masyarakat untuk bertransaksi. Beberapa kemudahan yang dimiliki uang digital ialah masyarakat tidak perlu membawa uang kertas dalam jumlah besar, sarana prasarana (perangkat dan jaringan) pendukung tersedia di hampir seluruh tempat transaksi, tampilan dan fitur yang sederhana, dan tidak memerlukan biaya tambahan dalam penggunaannya. Berbagai kemudahan tersebut merupakan dasar pertimbangan masyarakat untuk memutuskan bermigrasi dari uang kertas ke uang digital.

\section{Pengaruh Aktivitas Promosi Terhadap Keputusan Penggunaan Uang Digital}

Hasil pengujian hipotesis menunjukkan bahwa promosi uang digital tidak berpengaruh terhadap keputusan penggunaan uang digital. Hasil tersebut tidak sejalan dengan penelitian terdahulu bahwa aktivitas promosi memengaruhi keputusan untuk menggunakan uang digital [7].

Kegiatan promosi bertujuan untuk memperkenalkan produk barang/jasa kepada khalayak. Uang merupakan bagian dari kegiatan transaksi yang dilakukan sehari-hari sehingga adanya proses transformasi dari uang konvensional ke uang digital tidak memerlukan terlalu banyak kegiatan promosi namun lebih menekankan kepada penyajian informasi terkait kemudahan dan kemanfaatannya. Temuan ini juga menunjukkan bahwa konsumen semakin kritis terhadap suatu produk barang/jasa sehingga tidak menjadikan faktor promosi sebagai satu-satunya penentu untuk membeli atau menggunakan suatu barang/jasa.

\section{Pengaruh Kemanfaatan Terhadap Keputusan Penggunaan Uang Digital}

Kesimpulan yang diperoleh dari analisis statistik membuktikan bahwa manfaat yang ditawarkan oleh penyedia uang digital berpengaruh signifikan terhadap keputusan masyarakat untuk menggunakan uang digital. Hasil tersebut sejalan dengan beberapa penelitian 
sebelumnya bahwa manfaat yang ditawarkan oleh barang/jasa memengaruhi keputusan penggunaan [20], [3], [4].

Manfaat dari hadirnya uang digital ialah proses transaksi yang efektif sehingga pengguna memiliki waktu lowong untuk melakukan aktivitas lainnya. Hadirnya proses transaksi yang ringkas dan cepat merupakan kebutuhan generasi milenial yang dituntut memilki kemampuan multi-tasking atau menyelesaikan banyak pekerjaan dalam suatu interval waktu yang singkat.

\section{Pengaruh Kemudahan, Promosi, dan Kemanfaatan Terhadap Penggunaan Uang Digital}

Hasil penelitian menemukan bahwa faktor kemudahan, promosi, dan kemanfaatan berpengaruh secara signifikan terhadap keputusan penggunaan uang digital. Interpretasi dari hasil tersebut dan kaitannya dengan hasil pengujian hipotesis sebelumnya ialah promosi uang digital tidak dapat berdiri sendiri namun akan berpengaruh pada keputusan penggunaan uang digital bila dikolaborasikan dengan variabel kemudahan dan kemanfaatan serta peningkatan pemahaman atas resiko terkait penggunaan uang digital [24].

\section{KESIMPULAN}

Berdasarkan hasil dan pembahasan yang telah diuraikan maka dapat disimpulkan bahwa faktor kemudahan dan kemanfaatan berpengaruh positif dan signifikan terhadap keputusan penggunaan uang digital sedangkan aktivitas promosi tidak berpengaruh signifikan. Akan tetapi secara simultan kemudahan, promosi, dan kemanfaatan berpengaruh secara bersamasama terhadap keputusan penggunaan uang digital.

Faktor kemudahan dan kemanfaatan dari uang digital merupakan faktor yang perlu mendapat perhatian serius mengingat kedua faktor tersebut berpengaruh secara nyata terhadap keputusan masyarakat menggunakan uang digital. Aktivitas promosi uang digital tetap perlu diperhatikan karena ketiga faktor tersebut secara bersama dapat meningkatkan keyakinan masyarakat agar menggunakan uang digital.

Penggunaan uang digital merupakan hal baru di masyarakat sehingga penelitian terkait faktor yang memengaruhi penggunaan uang digital masih dapat dikembangkan. Untuk peneliti selanjutnya dapat melakukan perluasan cakupan penelitian dan pengembangan faktor-faktor lain yang mempengaruhi penggunaan uang digital. 


\section{DAFTAR PUSTAKA}

[1] Peraturan Bank Indonesia nomor 11/12/PBI tahun 2009 tentang Uang Elektronik (Electronic Money).

[2] Bank Indonesia. 2018. Jumlah uang elektronik tahun 2009 - 2017.

[3] Fontes, Tania, V. Costa, M.C. Ferreira, L. Shengxiao, P. Zhao, dan T.G. Dias. 2017. Mobile payments adoption in public transport. Transport Research Procedia, 24: 410-417.

[4] Di Pietro, L. R.G. Mugion, Matia R., M.F. Renzi, M. Toni. 2015. The integrated Model On Mobile Payment Acceptance (IMMPA): An Empirical Application To Public Transport. Transportation Research Part C: Emerging Technologies, 56: 463-479.

[5] Latief, Fitri dan Nur, Yuswari. 2019. Technology Acceptance Model (TAM) Terhadap Minat Konsumen Sistem Pembayaran GoPay pada Layanan GoJek. Bongaya Journal for Research in Management, 2(2) : 1-11.

[6] Rohmah, Farida. 2018. Perkembangan Uang Elektronik pada Perdagangan di Indonesia. Jurnal Bisnis dan Manajemen Islam, 6(1) : 1-19.

[7] Adiyanti, Arsita I. 2015. Pengaruh Pendapatan, Manfaat, Kemudahan Penggunaan, Daya Tarik Promosi, Dan Kepercayaan Terhadap Minat Menggunakan Layanan E-Money. Jurnal Ilmiah Mahasiswa Fakultas Ekonomi dan Bisnis Universitas Brawijaya: Vol. 3 (1).

[8] Cecchetti, Stephen G. dan Scoenholtx, Kermit L. 2015. Money, Banking, and Financial Markets. Singapore: McGraw Hill Education.

[9] Mishkin, Frederic S. 2008. Ekonomi Uang, Perbankan, dan Pasar Keuangan. Edisi 8. Jakarta: Salemba Empat.

[10] Jogiyanto, Hartono. 2011. Analisis Desain Sistem Informasi: Pendekatan Terstruktur Teori dan Praktik Aplikasi Bisnis. Yogyakarta: Andi.

[11] Amijaya, G. Rizky. 2010. Pengaruh Persepsi Teknologi Informasi, Kemudahan, Resiko, dan Fitur Layanan Terhadap Minat Ulang Nasabah Bank dalam Menggunakan Internet Banking. UNDIP, Semarang.

[12] Venkatesh, Viswanath, M.G. Morris, G.B. Davis, dan F.D. Davis. 2003. User Acceptance of Information Technology: Toward a Unified View. MIS Quarterly, 27(3).

[13] Kurtz, David L. Boone. 2013. Principle of Contemporary Marketing. $14^{\text {th }}$ Edition. USA: Cengage Learning. 
[14] Buchari, Alma. 2011. Manajemen Pemasaran dan Pemasaran Jasa. Bandung: Alfabeta.

[15] Kotler, Phillip dan K.L. Keller. 2012. Marketing Management. 14 Edition. New Jersey: Prentice Hall.

[16] Rahmatsyah, Deny. 2011. Analisis Faktor-Faktor yang Mempengaruhi Minat Penggunaan Produk Baru. Skripsi STIE Perbanas Surabaya.

[17] Adamson, I. dan J. Shine. 2003. Extending The New Technology Acceptance Model To Measure The End User Information Systems Satisfaction In A Mandatory Environment: A Bank Treasury. Technology Analysis \& Strategic, 15.

[18] Sangadji, E. Mamang dan Sopiah. 2013. Metodologi Penelitian. Yogyakarta: Andi.

[19] Indrayanto, I. Deshapri, Kertahadi, dan Susilo. 2015. Pengaruh persepsi kemanfaatan dan sikap pengguna online shop terhadap minat menggunakan rekening bersama. Jurnal Administrasi Bisnis, 13(1).

[20] Novianti, A Widya, D. Partomo, dan Kurnia. 2017. Faktor Penentu Minat Penggunaan Instagram Untuk Pembelan Online Menggunaan TAM. Jurnal $e$ Proceeding of Management: Vol.4 (2).

[21] Rafidah, Inas. 2017. Analisis Keamanan, Kemudahan, Dan Kepercayaan Terhadap Keputusan Pembelian Secara Online di Lazada. Jurnal Ilmu dan Riset Manajemen, 6(2).

[22] Sugiyono. 2012. Metode Penelitian Kuantitatif Kualitas dan R\&D. Bandung: Alfabeta.

[23] Riduwan dan Akdon. 2013. Rumus dan Data dalam Analisis Statistika. Bandung: Alfabeta.

[24] Wu, Jinnan, Lin Liu, dan Lihua Huang. 2017. Consumer Acceptance Of Mobile Payment Across Time: Antecedents And Moderationg Role Of Diffusion Stages. Industrial Management \& Data Systems, 117(8) : 1761-1776. 